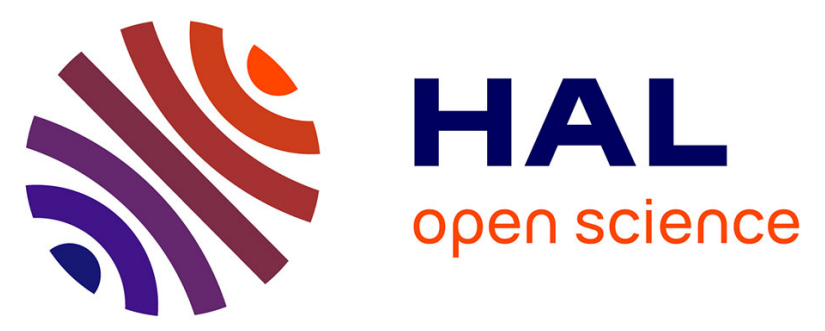

\title{
Efficacy of bortezomib in refractory form of multicentric Castleman disease associated to poems syndrome (MCD-POEMS variant)
}

Marta Anna Sobas, Natalia Alonso Vence, Jose Diaz Arias, Angeles Bendaña Lopez, Maximo Fraga Rodriguez, Jose Luis Bello Lopez

\section{To cite this version:}

Marta Anna Sobas, Natalia Alonso Vence, Jose Diaz Arias, Angeles Bendaña Lopez, Maximo Fraga Rodriguez, et al.. Efficacy of bortezomib in refractory form of multicentric Castleman disease associated to poems syndrome (MCD-POEMS variant). Annals of Hematology, 2009, 89 (2), pp.217-219. 10.1007/s00277-009-0795-6 . hal-00535081

\section{HAL Id: hal-00535081 https://hal.science/hal-00535081}

Submitted on 11 Nov 2010

HAL is a multi-disciplinary open access archive for the deposit and dissemination of scientific research documents, whether they are published or not. The documents may come from teaching and research institutions in France or abroad, or from public or private research centers.
L'archive ouverte pluridisciplinaire HAL, est destinée au dépôt et à la diffusion de documents scientifiques de niveau recherche, publiés ou non, émanant des établissements d'enseignement et de recherche français ou étrangers, des laboratoires publics ou privés. 


\title{
Efficacy of bortezomib in refractory form of multicentric Castleman disease associated to poems syndrome (MCD-POEMS variant)
}

\author{
Marta Anna Sobas • Natalia Alonso Vence • \\ Jose Diaz Arias • Angeles Bendaña Lopez • \\ Maximo Fraga Rodriguez • Jose Luis Bello Lopez
}

Received: 23 April 2008 / Accepted: 14 July 2009 / Published online: 28 July 2009

(C) Springer-Verlag 2009

\section{Dear Editor,}

Castleman's disease is a rare lymphoproliferative disorder with a variable clinical course [1]. Multicentric Castleman disease (MCD) presents with generalized lymphadenopathy, hepatosplenomegaly, fever, and night sweats, and aggressive treatment is required [2]. Viral infections, autoimmunity disorders, and altered cytokine (IL-6) regulation have been implicated in CD pathogenesis $[2,3]$. The association between CD and POEMS syndrome is well known [4].

A 49-year-old male, diagnosed of depressive disorder, and dysmyelinating peripheral polyneuropathy presented in June 2001 with asthenia, anorexia, generalized edema, and diarrhea. Physical examination revealed rash, left axial adenopathy, and distal dysesthesia in superior extremities. Normochromic anemia with slight leukocytosis was observed. Total protein and immunoglobulin levels were normal. No monoclonal protein was detected. Beta-2 microglobulin was increased to $3.19 \mathrm{mg} / \mathrm{L}$ (normal $=0.3-$ $2.1 \mathrm{mg} / \mathrm{L}$ ). LDH levels and hepatic and kidney functions were normal. Osteosclerotic lesions in ribs were detected on radiographs. Bone marrow biopsy was infiltrated by polyclonal linfo-plasmoctic population. A computed to-

M. A. Sobas $(\bowtie) \cdot$ N. Alonso Vence $\cdot$ J. Diaz Arias

A. Bendaña Lopez $\cdot$ J. L. Bello Lopez

Servicio de Hematologia y Hemoterapia,

Hospital Clinico Universitario de Santiago de Compostela,

c/Choupana $\mathrm{s} / \mathrm{n}$,

15-706 Santiago de Compostela, Spain

e-mail: marta.sobas@gmail.com

\section{Fraga Rodriguez}

Servicio de Anatomia Patologica,

Hospital Clinico Universitario de Santiago de Compostela,

Santiago de Compostela, Spain mography (CT) scan showed multiple intra-abdominal adenopathies, splenomegaly with ascites, and pleural effusion. An axial node biopsy was nondiagnostic, and abdominal lymph node biopsy was compatible with $\mathrm{CD}$ (Fig. 1). On the days following biopsy, a rapid progression of ascites and pleural effusion with subsequent hemodynamic instability was observed. A thoracocentesis showed exudative pleural fluid with increased IL-6 levels reaching $1,640 \mathrm{pg} / \mathrm{mL}$. Serum IL-6 levels were increased to $69.8 \mathrm{pg} /$ $\mathrm{mL}$ (normal $<5 \mathrm{pg} / \mathrm{mL}$ ). Clinical improvement was achieved by intravenous steroid therapy. Screening for human immunodeficiency virus (HIV) and human herpes virus-8 (HHV-8) was negative. Throughout the following 2 years, the patient was asymptomatic with low dose of steroids. In 2003, progression of ascites and pleural effusion was observed, and anti-CD20 antibodies (Rituximab $375 \mathrm{mg} / \mathrm{m}^{2}$, four doses weekly) was applied without any response. In 2004, four courses of CHOP (excluding vincristine, so as not to worsen the patient's polyneuropathy) were administered with a partial response. In subsequent years, the patient experienced progressive deterioration with asthenia, anorexia, weight loss, and an increase in ascites and pleural effusion. The condition was moderately sensitive to repeated steroid treatment; however, in 2005, he was admitted because of an esophagus variceal hemorrhage, and Budd-Chiari syndrome was diagnosed by CT study. In 2006, primary hypothyroidism was detected, and supplementary therapy was started. In 2006, due to the lack of treatment response and no other available therapeutic options, informed consent was obtained to initiate therapy with bortezomib at a dosage of $1.3 \mathrm{mg} / \mathrm{m}^{2}$ combined with $20 \mathrm{mg}$ of dexamethasone on days $1,4,8$, 11 , repeated at day 22 for a total of six cycles. A strict control of neurological toxicity of bortezomib was per- 

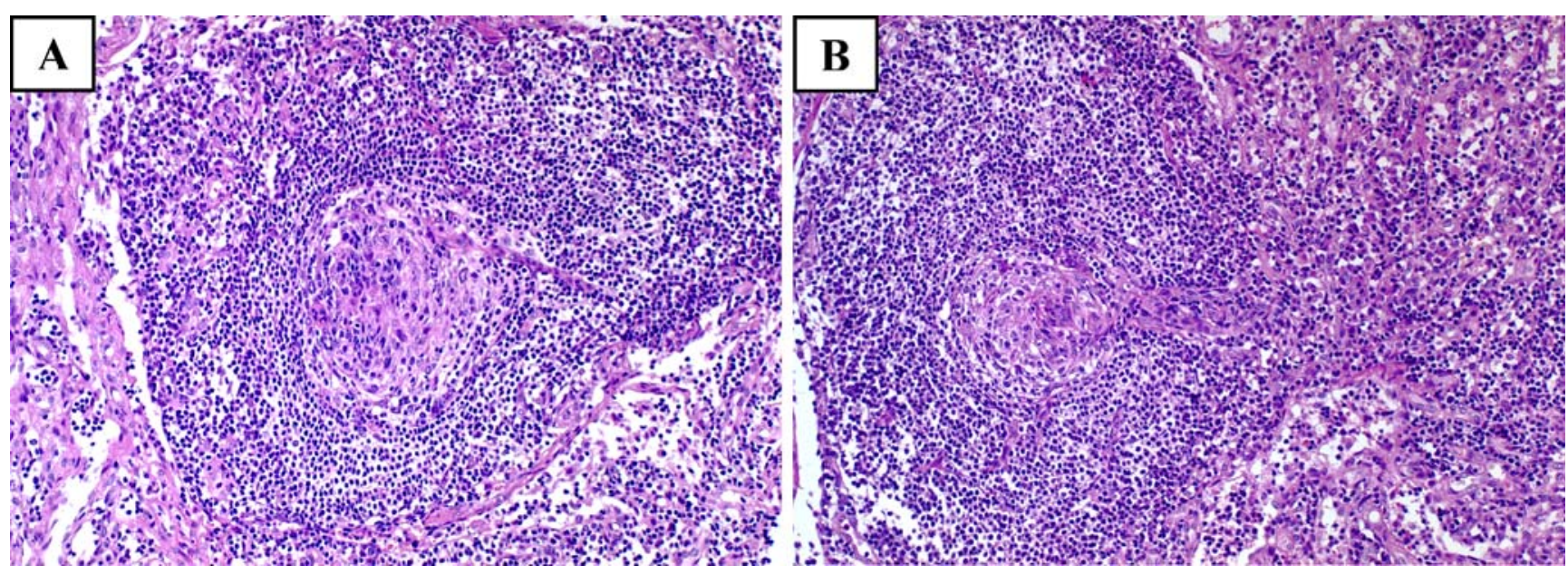

Fig. 1 a, b Typical hyaline-vascular follicles with onion-skin-like placement of small lymphocytes around atrophic germinal centers; germinal centers are predominated by follicular dendritic cells and penetrated by venules. Right half in $\mathbf{b}$ shows interfollicular area rich in venules

formed, as the patient presented peripheral polyneuropathy. The treatment was well tolerated, and after the third cycle, improvement was observed (Table 1). Four years later, the patient remains in complete remission.

The diagnosis of MCD is based on lymph node histopathology study, presence of multiple adenopathies, and constitutional symptoms [2]. However, in our patient, the presence of peripheral neuropathy, primary hypothyroidism, effusions, and skin changes forced us to change the diagnosis to MCD-POEMS variant [4]. According to the literature, polyclonal hypergammaglobulinemia is often present [4]. In the present case, polyclonal hypergammaglobulinemia was found and no monoclonal protein was detected in spite of repeatedly performing immunofixation electrophoresis studies of serum and urine. We could not determine the clonality state of plasma cells from osteosclerotic lesions because biopsy consent was not obtained. As in the literature, polyclonal plasmatic cells were found in bone marrow study, and cytokine IL-6 levels were high [4].

There is still no consensus regarding the "gold standard" therapy in $\mathrm{CD}$ [2]. Chemotherapy (CHOP or CVAD) has shown response rates around $90 \%$, with $50 \%$ showing complete response [5]. In our patient's case, only a partial response was achieved. Steroids can control inflammation [2] and improve response rates. Although these effects may be transient, they appear in about $60 \%$ of patients [5]. Interferon-alpha (INF-alpha) has both immunoregulatory and antiviral properties, making it a potentially effective therapy for patients with MCD [2]. Thalidomide, similar to INF-alpha, also has immunomodulatory, anti-angiogenetic properties. In addition, thalidomide can decrease the production of IL-6 [2]. Our patient suffered from depressive disorder and polyneuropathy, thus, the reason why INFalpha and thalidomide were not used. Although therapeutic efficacy of antibody anti-IL6 receptor and anti-IL6 were reported [6,7], we did not have access to these drugs. Positive outcomes have been published regarding treatment with the anti-CD20 drug Rituximab [5]; in case of our patient, no response was obtained. Other therapeutic approaches such as the antiviral agents yielded nondurable response or no improvement $[8,9]$. As our patient was HIV and HHV-8 negative, antiviral agents were not used. Finally, good response to melphalan-based autologous transplant was observed in patients with neuropathy related to POEMS with or without CD [10]. Nevertheless, in this

Table 1 Therapy with bortezomib and patient outcome

\begin{tabular}{lll}
\hline & Pre-bortezomib & Post-bortezomib \\
\hline ECOG & 4 & 1 \\
Adenopathies & Axial, multiple mediastinic and intra-abdominal & Small retro-peritoneal \\
Pleural effusion and ascites & Progressive, no response to the treatment & Massively decreased \\
Heptoesplenomegaly & Progressive, no response to the treatment & Small splenomegaly \\
Dysmyelinating peripheral polyneuropathy & Distal dysesthesia in superior extremities & Clear improvement \\
B2M (mg/L) & April 2006, 10.5 & May 2007, 3.33 \\
IL-6 (pg/mL) & August 2006, 16.5 & February 2006, 4.2 \\
\hline
\end{tabular}


case, the autologous transplant was ruled out because of poor performance status of the patient.

Based on efficacy of bortezomib against B-cell malignancies and the experience in MCD described by Hess et al. [3], we decided to use bortezomib in a patient diagnosed with MCD-POEMS variant, refractory to previous treatment. The treatment was well tolerated, and the patient showed a definitive clinical improvement and sustained reduction of IL- 6 cytokines requiring no further treatment after 4 years. The therapeutic efficacy demonstrated in this case by bortezomib supports the initiation of clinical studies evaluating the potential impact of this drug in the treatment of MCD.

\section{References}

1. Castleman B, Iverson L, Mendez VP (1956) Localizad mediastinal lymph node hyperplasia resembling thymoma. Cancer 9:822830

2. Casper C (2005) The aetiology and management of Castelman disease at 50 years: translating pathophysiology to patient care. $\mathrm{Br}$ J Haematol 129:3-17

3. Hess G, Wagner V, Kreft A, Heussel CP, Huber Ch (2006) Effects of bortezomib on pro-inflammatory cytokine levels and transfu- sion dependency in a patient with multicentric Castelman disease. Br J Haematol 134:544-549

4. Dispenzieri A (2007) POEMS syndrome. Blood Rev 21:285-299

5. Ocio EM, Sanchez-Guijo FM, Diez-Campelo M, Castilla C, Blanco OJ, Caballero D, San Miguel J (2005) Efficacy of Rituximab in an aggressive form of multicentric Castleman disease associated with immune phenomena. Am J Hematol 78:302-305

6. Nishimoto N, Kanakura Y, Aozasa K, Johkoh T, Nakamura M, Nakano S, Nakano N, Ikeda Y, Sasaki T, Nishioka K, Hara M, Taguchi H, Kimura Y, Kato Y, Asaoku H, Kumagai S, Kodama F, Ankara H, Hagihara K, Yoshizaki K, Kishimoto $\mathrm{T}$ (2005) Humanized anti-interleukin-6 receptor antibody tratment of multicentric Castelman disease. Blood 106:26272632

7. Beck JT, Hsu SM, Wijdenes J et al (1994) Brief report: alleviation of systemic manifestations of Castleman's disease by monoclonal anti-interleukin- 6 antibody. $\mathrm{N}$ Engl $\mathrm{J}$ Med 330:602-605

8. Casper C, Nichols WG, Huang ML, Corey L, Wald A (2004) Remission of HHV-8 and HIV-associated multicentric Castleman disease with ganciclovir treatment. Blood 103:16321634

9. Berezne A, Agbalika F, Oksenhendler E (2004) Failure of cidofovir in HIV-associated multicentric Castleman disease. Blood 103:4368-4369

10. Hogan WJ, Lacy MQ, Wiseman GA, Fealey RD, Dispenzieri A, Gertz MA (2001) Successful treatment of POEMS syndrome with autologous hematopoietic progenitor cell transplantation. Bone Marrow Transplant 28(3):305-309 